\title{
Automatization of membrane contactors and applications for the management of dissolved gases in wines
}

\author{
P. Schonenberger ${ }^{1}$, J. Ducruet ${ }^{2}$, A. Pernet ${ }^{1}$, F. Marsan ${ }^{1}$, B. Bach ${ }^{1}$, P. Passeraub ${ }^{3}$, D. Zufferey ${ }^{4}$, and O. Vorlet ${ }^{4}$ \\ ${ }^{1}$ Changins, Rte de Duillier 50, 1260 Nyon, Switzerland \\ ${ }^{2}$ Inter Rhône, 2260 Rte du Grès, 84100 Orange, France \\ ${ }^{3}$ Hepia Biotech, Ch des Mines 9, 1202 Genève, Switzerland \\ ${ }^{4}$ Hefr, Bd de Pérolles 80, 1700 Fribourg, Switzerland
}

\begin{abstract}
Over the last decade, several distinct research groups tested possible uses of membrane contactors for the wine industry, notably for the management of dissolved gases in wines, adjustment of the $\mathrm{CO}_{2}$ concentration while reducing the $\mathrm{O}_{2}$ concentration at the same time. Other experiments were done with partial alcohol reduction and addition of $\mathrm{N}_{2}$ to wines. The contactor's heart is its Liqui-Cel ${ }^{\mathrm{TM}}$ membrane where the two separate circuits meet. The membrane's hydrophobic characteristics allows a liquid to get in contact with a gas, without dispersing into it. The directions that these gases take through the membrane depend on their partial pressure differences within the two circuits. However, other factors need to be considered to determine exact exchange rates for each target gas. The present article describes the new membrane contactor prototype that was co-developed by the University of applied Sciences and Arts, Viticulture and Enology at Changins, Switzerland, and the School of Engineering and Architecture at Fribourg, Switzerland. The prototype was designed for small scale operations. Flow rates, temperatures and internal pressures can be instantly measured and graphically visualized. Also, $\mathrm{O}_{2}$ concentrations are measured inside the liquid. $\mathrm{CO}_{2}$ concentrations in the liquid can be measured with a device that is connected to the liquid circuit through a bypass after the membranes.
\end{abstract}

\begin{abstract}
Zusammenfassung. Während mehr als zehn Jahren testeten verschiedene Forschungsgruppen Einsatzmöglichkeiten von Membran-Kontaktoren für die Weinindustrie. Im Besonderen wurde die genaue Einstellung von gelösten Gasen im Wein untersucht, z. B. die Anpassung der $\mathrm{CO}_{2}$-Konzentration und gleichzeitige Reduzierung der $\mathrm{O}_{2}$-Konzentration. Teilweise Alkoholreduktion und Zugabe von $\mathrm{N}_{2}$ zum Wein sind weitere Möglichkeiten. Das Herzstück des Kontaktors ist seine Liqui-Cel ${ }^{\mathrm{TM}}-\mathrm{Membran}$, wo sich zwei getrennte Kreisläufe treffen. Die wasserabstossenden Eigenschaften der Membran ermöglichen es einer Flüssigkeit, mit einem Gas in Kontakt zu treten, ohne sich darin zu verteilen. Die Richtung, die diese Gase durch die Membran nehmen, hängt von ihren unterschiedlichen Partialdrücken innerhalb der beiden Kreisläufe ab. Es müssen jedoch noch andere Faktoren berücksichtigt werden, um den genauen Austausch für jedes Gas zu ermitteln. Dieser Artikel beschreibt den neuen Prototyp eines Membran-Kontaktors, der von den Fachhochschulen für Weinbau und Önologie in Changins, Schweiz, und für Technik und Architektur in Freiburg, Schweiz, entwickelt wurde. Der Prototyp ist für die Anwendung mit kleinen Mengen vorgesehen. Fliessgeschwindigkeiten, Temperaturen und interner Druck können inline gemessen und grafisch dargestellt werden. Auch die $\mathrm{O}_{2}$-Konzentration kann im Flüssigkeitskreislauf gemessen werden. Die Konzentration von $\mathrm{CO}_{2}$ in der Flüssigkeit kann mit einem Gerät, welches nach den Membranen über einen Bypass an den Flüssigkeitskreislauf angeschlossen ist gemessen werden.
\end{abstract}

\section{Introduction}

Liquid-gas (and liquid-liquid) contacting operations have attracted research and development departments for a diverse range of applications. In the 1970s, blood oxygenation and decarbonation was already performed and did improve remarkably the understanding of the technology. The beverage industry (Pepsi bottling plant, West Virginia, USA) started to operate a foam-free, membrane-based carbonation line in the 1990s. Soon after, similar devices were used in the production of beer, where several breweries used the technology for $\mathrm{CO}_{2}$ removal, followed by nitrogenation to obtain a dense foam head, also $\mathrm{O}_{2}$ removal from beers to preserve flavor (Gabelmann and Hwang, 1999; Klassen and Jansen, 2001). Several distinct research groups tested possible uses of membrane contactors for the wine industry (Schmidt et al., 2008; Blank et Vidal, 2013; Schonenberger et al., 2014), notably for the management of dissolved gases in wines, e.g. adjustment of the $\mathrm{CO}_{2}$ concentration while reducing the $\mathrm{O}_{2}$ concentration at the same time. Other tests included partial alcohol reduction and addition of $\mathrm{N}_{2}$ to wines. Thanks to the initiative of Changins and the strong support of other member states (Germany, France), the OIV has recognized the 

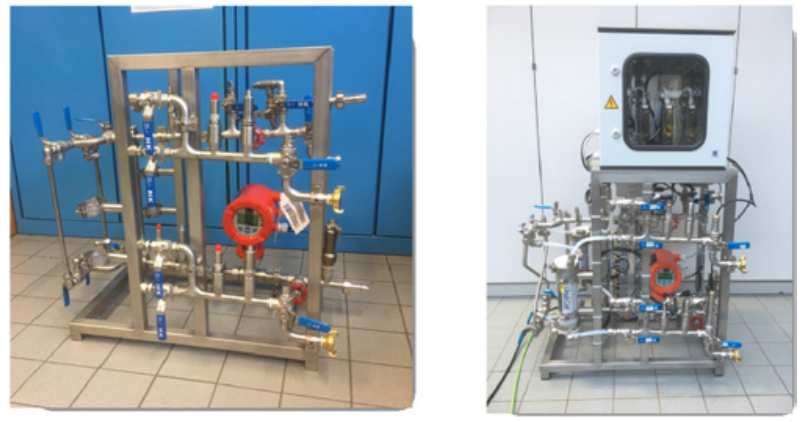

Figure 1. New membrane contactor prototype.

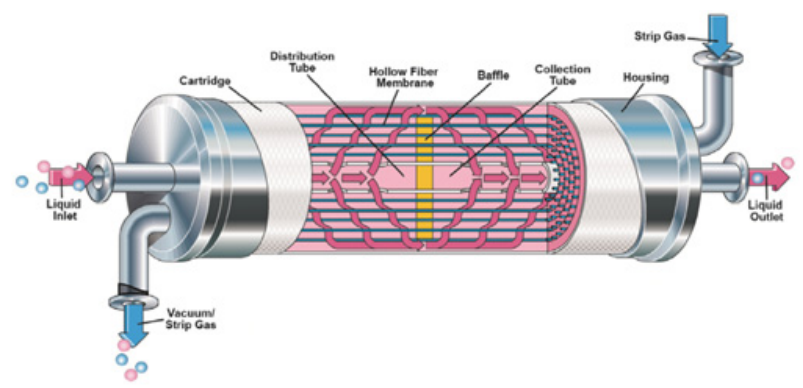

Figure 2. Liqui-Cel ${ }^{\mathrm{TM}} 2.5 \times 8 \times 50$ extra-flow membrane.

use of membrane contactors in the field of enology for the management of gases (Resolution OIV-OENO 499-2013). In the meantime, the OIV resolution has permitted to authorize the technology for grape musts and wines. The present article summarizes the technical description of a new membrane contactor prototype built for small-scale wineries and laboratory research projects with flow rates between one and twelve liters per membrane and minute (which equals a maximum of 720 liters per membrane and hour).

\section{The prototype and its applications}

The University of applied Sciences and Arts, Viticulture and Enology at Changins, Switzerland, and the School of Engineering and Architecture at Fribourg, Switzerland, codesigned and developed the membrane contactor prototype (Fig. 1) to carry out tests related to the management of dissolved gases in wines and the membrane's transfer efficiencies during extended running times for the addition and the removal of different gases in wines.

Two Liqui-Cel ${ }^{\mathrm{TM}} 2.5 \times 8 \times 50$ extra-flow membranes (Fig. 2) from the $3 \mathrm{M}^{\mathrm{TM}}$ company (Charlotte, North Carolina, USA) were integrated into the prototype. The prototype was designed for the use of one or two membranes individually, in series or in parallel. The membranes are built of multiple spaghetti type, hollow fiber capillaries with an internal diameter of $240 \mu \mathrm{m}$ and an average porosity size of $0.05 \mu \mathrm{m}$. The contact surface inside each membrane is $1.4 \mathrm{~m}^{2}$ and the internal volume of the membrane module is 0.55 liters. in general, the liquid runs at the outside (shell side) of the capillaries and the gas at the inside (lumen side). Gases are exchanged across the pores, while the liquid and the gas flow along different sides of the capillaries.

Thanks to the hydrophobic characteristics of the membrane, the liquid flows over the membrane but doesn't

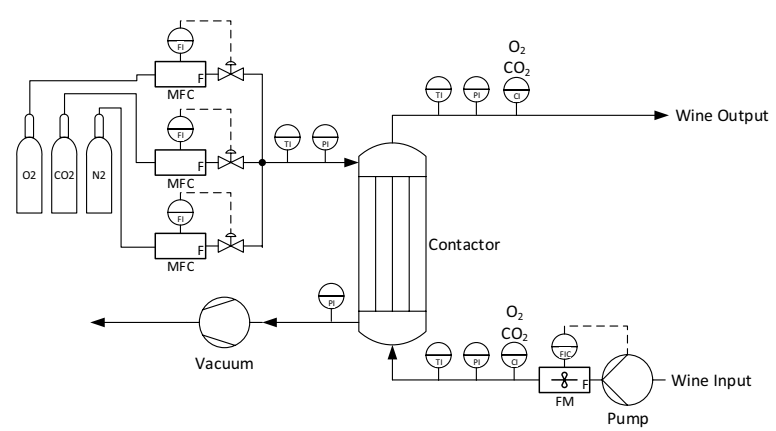

Figure 3. Simplified scheme of the prototype.

enter the pores. Whenever the partial pressure of a given gas is greater in the lumen side than it is in the shell side, the gas crosses the pores from the inside of the capillary outward and dissolves into the liquid. On the other hand, whenever the partial pressure is smaller in the lumen side than in the shell side, the gas contained in the liquid is passing the pores towards the lumen side. Thus, by regulating the concentration of a gas in the lumen side it is possible to control the dissolved gas content in the liquid of the shell side.

With the new membrane contactor prototype new possibilities for the study of gas exchange processes in grape musts and wines emerged. Different points of measurements are included in the two circulation lines (Fig. 3). In the liquid circuit, measurements of the liquid flow, the $\mathrm{O}_{2}$ concentration, the internal pressure, and the temperature between the inlet valve and the membrane are included. After the membrane the $\mathrm{O}_{2}$ concentration, the internal pressure, and the temperature can be measured. In addition, a bypass was added after the membrane and just before the outlet valve for measurements of the $\mathrm{CO}_{2}$ concentration. The gas circuit includes measurements of the internal pressure and the temperature before the membrane. After the membrane, the internal pressure, temperature, and the $\mathrm{O}_{2}$ concentration can be measured.

Valves in both circulation lines made two distinct running modes possible: The removal mode and the injection mode. The removal mode is regulated by the inlet valve of the gas circuit, which is equipped with a vacuum pump at the outlet. The inlet valve is gradually closed to decrease the pressure by the vacuum pump within the gas circuit and to increase the gas transfer rates from the liquid circuit to the gas circuit. Consequently, this results to the decrease of the gas concentration within the liquid. On the other hand, the injection mode is regulated by the outlet valve of the gas circuit, which is connected to a gas bottle at the inlet. The outlet valve is gradually closed to increase the pressure within the gas circuit and the gas transfer rates to the liquid circuit is increased, too. Consequently, this results to the increase of the gas concentration within the liquid. A third possible running mode is a combination of the two modes that are described above: The combo mode, which is a sweep-assisted vacuum mode. The gas circuit is equipped with a gas bottle at the inlet and a vacuum pump at the outlet for the combo mode. This mode is regulated by both, the inlet valve and the outlet valve of the gas circuit. Both valves are never completely closed for the combo mode. Consequently, the strip gas from the connected gas bottle can be added to the liquid and at the same time it 


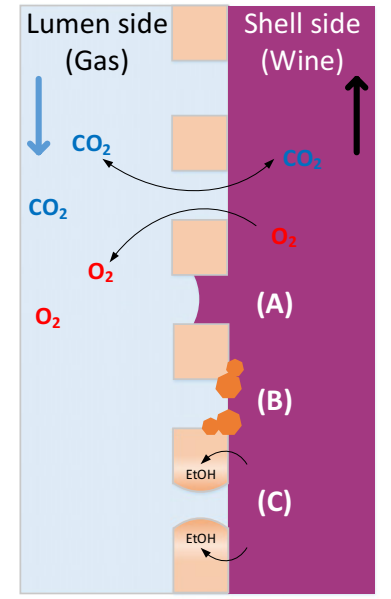

Figure 4. Loss of transfer efficiency through the membrane by: (A) wetting out of the membrane because the pressure difference is too high; (B) particle clogging by distinct wine components; (C) membrane deformation through diffusion of high alcohol concentrations in the membrane.

sweeps other gases that are removed from the liquid circuit permanently away from the gas circuit for a maximum gas removal efficiency.

Flow rates and internal pressure are measured within both circuits. As mentioned above, liquid flow rates may be regulated between 1 and 12 liters per minute and membrane module, which equals up to a maximum of 24 liters perminute if the two membrane modules are running in parallel. The two membranes can also be running in series. The latter configuration allowed to increase and finetune the transfer efficiency of an individual gas in one single passage of the liquid.

The PreSens ${ }^{\circledR}$ technology (Präzisionsmessung, Regensburg, Deutschland) was integrated for the measurements of $\mathrm{O}_{2}$ concentrations. It uses electroluminescence, which has the advantage of being non-invasive, nondestructive and fast. This method is the most recent used for the measurement of $\mathrm{O}_{2}$ in wine, it also allows easy automatization for the inline measurement of dissolved oxygen.

\section{Considerations for the automatization}

The membrane's loss of gas transfer efficiency after an extended time of use posed a constant concern. Three mechanisms at the level of the membrane appeared to be at the source of that loss (Fig. 4). Wetting out of the membrane is caused by a significant pressure differential between the shell side and the lumen side, which again can cause the liquid to enter the pores of the capillaries and, at the same time, inhibit the gases from easily penetrating and transferring to either side of the capillaries. Particle clogging of the contactor's shell side is another source of transfer efficiency loss. In terms of wines, particles that can clog the shell side belong primarily to the polyphenol, polysaccharide, or protein families. Also, a third source is important to consider when transfer efficiency loss is experienced: Increased alcohol concentrations of the liquid can change the hydrophobic characteristics of the membrane and at a certain concentration even deform the pores and the capillaries, which may be non-reversible.

\section{References}

[1] R. Klaassen, A. Jansen, Environ. Prog. 20, 37 (2001)

[2] A. Gabelmann, S.T. Hwang, J. Membrane Sci. 159, 61 (1999)

[3] O. Schmidt, J. Ulbrich, G. Waidelich, Deutsche Weinmagazin. 5, 20 (2008)

[4] A. Blank, J.C. Vidal, Revue française d'œnologie. 261, 7 (2013)

[5] P. Schonenberger, I. Baumann, A. Jaquerod, J. Ducruet, Am. J. Enol. Vitic. 65 (2014) 